\title{
Avaliação da Atividade Antimicrobiana de Extratos Vegetais de Espécies do Cerrado Frente A Isolados Clínicos de Staphylococcus aureus Resistente À Meticilina (MRSA)
}

Alyson Mykael Albuquerque Florenço (III), Thaís Soares da Silva (III), João Geraldo Carvalho Fernandes (I), Thiago Antônio de Sousa Araújo (I), Elba Lucia Cavalcanti de Amorim (I), Maria Cristina da Silva Pranchevicius (II), Isabella Macário Ferro Cavalcanti

(I) UFPE - Universidade Federal de Pernambuco (Av. Prof. Moraes Rego, 1235 - Cidade Universitária, 50670-901, Recife, PE), (II) UFT - Universidade Federal do Tocantins ( Avenida

NS 15, 109 Norte - Plano Diretor Norte - Palmas - TO, 77001-090 Brasil ), (III) UFPE Universidade Federal de Pernambuco (Rua do Alto do Reservatório s/n, Bela Vista, 55608-680, Vitória de Santo Antão)

\section{Resumo}

Introdução: A comunidade científica tem empreendido esforços para desenvolver ou descobrir novas classes de antibióticos, especialmente a partir de produtos de origem natural empregados na medicina popular. Diversos micro-organismos estão envolvidos nas infecções nosocomiais, tendo destaque para o Staphylococcus aureus resistentes à meticilina (MRSA), uma vez que esta bactéria é causa frequente de morbimortalidade, principalmente em pacientes imunodeprimidos. Desta forma, o objetivo deste estudo foi avaliar a atividade antimicrobiana de extratos vegetais de espécies coletadas no Cerrado brasileiro frente a isolados clínicos de MRSA. Material e Métodos: Inicialmente foram preparados extratos brutos etanólicos e extratos fracionados (hexano, diclometano e etanol) de 4 plantas do Cerrado. Os nomes das plantas não serão divulgados, uma vez que estamos em trâmites de depósito de patente. O extrato da fração etanólica e o extrato bruto foram utilizados para testar a atividade

\footnotetext{
Referência:

Alyson Mykael Albuquerque Florenço, Thaís Soares da Silva, João Geraldo Carvalho Fernandes, Thiago Antônio de Sousa Araújo, Elba Lucia Cavalcanti de Amorim, Maria Cristina da Silva Pranchevicius, Isabella Macário Ferro Cavalcanti. Avaliação da Atividade Antimicrobiana de Extratos Vegetais de Espécies do Cerrado Frente A Isolados Clínicos de Staphylococcus Aureus Resistente À Meticilina (Mrsa). In: Anais do 12을 Congresso Latinoamericano de Microbiologia e Higiene de Alimentos - MICROAL 2014 [= Blucher Food Science Proceedings, num.1, vol.1]. São Paulo: Editora Blucher, 2014.

DOI 10.5151/foodsci-microal-309
} 
antimicrobiana frente à MRSA pela determinação da concentração inibitória mínima (CIM) e a concentração bactericida mínima (CBM) pelo método da microdiluição em caldo de acordo com o Clinical and Laboratory Standards Institute (CLSI). Resultados e Discussão: Todos os extratos apresentaram atividade bacteriostática frente aos dez isolados clínicos de MRSA (CIM = $31-250 \mu \mathrm{g} / \mathrm{mL}$ ). Não houve diferença nos valores de CIM e CBM entre os extratos brutos e suas respectivas frações etanólicas. Dos extratos analisados os da casca e folha de uma das plantas parecem apresentar uma atividade antibacteriana mais efetiva, uma vez que seus valores de CIM sempre se apresentaram inferiores em relação aos demais. Adicionalmente, o extrato bruto obtido da folha de uma das plantas, assim como a sua fração, apresentaram efeito bactericida $(\mathrm{CBM}=$ $250 \mu \mathrm{g} / \mathrm{mL}$ ) frente a $50 \%$ dos isolados testados e o extrato bruto da casca desta mesma espécie, assim como sua fração, foram bactericida frente a $10 \%$ dos isolados. Conclusão: Desta forma, das espécies do Cerrado analisadas, os extratos brutos e as frações etanólicas das cascas e folhas de uma delas, parecem ser as melhores alternativas para o tratamento de infecções provocadas pelo MRSA

Palavras-Chave: Atividade antibacteriana, Extratos, Plantas do Cerrado, MRSA

\section{Agência de Fomento:}

